\title{
Quality Assessment of Different Industrial Effluents for Irrigation in Agriculture
}

\author{
M Rafiqul Islam¹, G K M Mustafizur Rahman², A J M Sirajul Karim², M Giasuddin Miah ${ }^{3}$ and M Abu Saleque ${ }^{4}$ \\ 1. Principal Scientific Officer, Soil Science Division, BRRI (Bangladesh Rice Research Institute), Gazipur 1701, Bangladesh \\ 2. Department of Soil Science, BSMRAU (Bangabandhu Sheikh Mujibur Rahman Agricultural University), Gazipur 1706, Bangladesh \\ 3. Department of Agroforestry and Environment, BSMRAU, Gazipur-1706, Bangladesh \\ 4. CASR (Coordinator for Advanced Studies and Research), BRRI, Gazipur 1701, Bangladesh
}

Received: January 15, 2015 / Accepted: January 25, 2015 / Published: February 25, 2015.

\begin{abstract}
A laboratory experiment was undertaken in Soil Science Division of BRRI (Bangladesh Rice Research Institute) during 2010 to assess the quality of industrial effluents and city waste as a source of irrigation water for agriculture. The treatments of the studies were the effluents of five different industrial sources like polyvinyl, dyeing, pharmaceuticals, beverage, tannery, mixed waste water (contaminated with effluents from many industries), CWW (city waste water) and underground water as control. The industrial effluents, MWW (mixed waste water), CWW and control water were tested for electrical conductivity, $\mathrm{pH}$, and soluble ions such as $\mathrm{Na}^{+}, \mathrm{Ca}^{2+}, \mathrm{Mg}^{2+}, \mathrm{K}^{+}, \mathrm{HCO}_{3}{ }^{-}, \mathrm{CO}_{3}{ }^{2-}, \mathrm{NH}_{4}{ }^{+}-\mathrm{N}$ and $\mathrm{H}_{2} \mathrm{PO}_{4}{ }^{-}$. Micronutrients (Fe, $\mathrm{Mn}, \mathrm{Cu}$ and $\mathrm{Zn}$ ) and heavy metals (As, $\mathrm{Pb}, \mathrm{Cd}, \mathrm{Cr}$ and $\mathrm{Ni}$ ) were analyzed from the samples. Beverage industry effluent showed acidic reaction, while the other industrial effluents showed alkaline reaction ( $\mathrm{pH}$ 7.25-9.07). Pharmaceutical, dyeing and tannery effluents showed EC of $3.40,4.30$ and $9.49 \mathrm{dS} \mathrm{m}^{-1}$, respectively, compared to $0.54 \mathrm{dSm}^{-1}$ of the control. All the effluents except polyvinyl and beverage effluents and CWW recorded higher carbonate and bicarbonate content than that of control. Industrial effluents and CWW were higher in micronutrient content as compared to control. Dyeing, pharmaceutical and tannery effluents contained 2.51, 3.94 and $4.29 \mathrm{mg} \mathrm{L}^{-1}$ lead, $0.15,0.14$ and 0.38 mg L $\mathrm{L}^{-1}$ chromium and $0.25,0.24$ and $0.16 \mathrm{mg} \mathrm{L}^{-1}$ nickel, respectively which might be concerned for health hazard through food chain.
\end{abstract}

Key words: Electrical conductivity, heavy metal content, sodium adsorption ration, soluble sodium percent, city waste water.

\section{Introduction}

Water is essential to all forms of life and makes up to $50 \%-97 \%$ of the weight of all plants and animals [1]. Irrigation of agricultural fields facilitated increasing cropping intensity, increased farm productivity and to some extent crop diversity. The quality of water has very important role for the sustainability of agriculture. With the limitation of surface water availability, farmers in Bangladesh increasingly utilizing underground water as an alternate source of irrigation water, which paved the way of increasing Boro cultivation throughout the country. Farmers prefer to grow Boro rice as long as

Corresponding author: Rafiqul Islam, Dr., research field: soil science. E-mail: rafiqbrri@yahoo.com. there is a source of water. Recently, expansion of industrial zone to the rural areas added available water to the farmers for irrigation. Farmers, often, have very easy access to the industrial effluents flowing out of the industry to their crop fields and use them for irrigation in dry season.

Industrial sector of Bangladesh grew up very rapidly due to its increased contribution to GDP coupled with increased incentives provided by the Government. Many of these industries poorly followed the industrial establishment rule and have been setup in vicinity of the cultivable areas and their untreated effluents became a threat to the crop field.

In some cases, the industrial effluents over flow the narrow canals and discharge to the canals and small 
rivers which results in the discolored foul smelly water in the river. Many of the industries, located along the Dhaka-Mymensingh high way, became the primary water sources, through their effluents, for some canals connecting to the Turag. Some industries discharge their effluents directly to the surrounding crop fields and farmers become obliged to accept these unwanted irrigation water. The type of industries contributing to the open effluent discharges include beverage, polyvinyl, pharmaceuticals, dyeing and tannery. Waste water of the municipality discharges out of the city is another contributor to the unplanned irrigation source to many crop fields. However, the quality of the industrial effluent as well as city waste water has scantly been reported [2-4]. Some effluents contain plant nutrients which enhance plants growth [5]. Soon [2, 3] studied the decomposition of organic compounds and the transport of NPK from the wastes to plants. It also contains toxic metals which contaminate the soil environment. Industrial effluents, if not treated and properly controlled can also pollute ground water [6, 7].

Various chemical pollutants such as nitrates, nitrites, fluorides, arsenic, copper, zinc, nickel, detergents, hydrocarbons and radio nucleoside are the components of the industrial effluents. Industrial effluents also carry oil, grease, gasoline and waste lubricating oil. Some of these spills cause obvious and even pronounced damage to plants, marine fishes, birds, as well as mammals [8]. The extent of damage of the toxic effluent adversely affect germination, root initiation, rate of root growth, stem growth, panicle emergence, and filling of rice grain [9]. In extreme cases the plant dies because of effluent water application. Kumar [9] also reported beneficial effects of organic effluents on plants. Agrawal [10] mentioned deleterious effect of ordnance factory effluent on pea seed germination and early growth. Therefore, the present study was planned to assess the quality of different industrial effluents as a source of irrigation water.

\section{Materials and Methods}

The experiment involves industrial effluents from polyvinyl, dyeing, pharmaceutical, beverage, tannery, mixed (canal water contaminated with effluents from many industries), city waste water and fresh underground water (control). Industrial effluent samples were collected from discharge points of Polyvinyl, Dyeing, Beverage, located at Banglabazar, Shreepur areas of Gazipur, Pharmaceutical industry from Bhalukha, Mymensingh and Tannery industries from Hazaribag, Dhaka. A mixed effluent sample was collected from a cannel that received discharge of different types of industrial effluents. Gazipur municipal waste was collected to represent city waste water. The control water was collected from a deep tube well, BRRI, Gazipur. Effluent samples were collected in clean plastic bottles. The bottles were rinsed several times with the sample water and then filled up with the samples and corked tightly immediately after collection and transferred to the laboratory. After filtration through (Whatman\#1), pH and EC (Electrical Conductivity) of the samples were immediately measured in the laboratory. The samples were stored at $4{ }^{\circ} \mathrm{C}$ for further analysis. The water quality analysis includes carbonate, bicarbonate, ammonium-nitrogen, phosphorus, calcium, magnesium, potassium, sodium, micronutrient (Fe, $\mathrm{Mn}, \mathrm{Cu}$ and $\mathrm{Zn}$ ) and heavy metals (As, $\mathrm{Pb}, \mathrm{Cd}, \mathrm{Cr}$ and $\mathrm{Ni}$ ) contents. Each measurement was done in triplicate. Sodium adsorption ratio and soluble sodium percentage were also determined.

\section{$2.1 \mathrm{pH}$}

A glass electrode $\mathrm{pH}$ meter (WPA Linton Cambridge, UK) calibrated with buffer $\mathrm{pH} 7.0$ and 4.0 was used to measure the $\mathrm{pH}$ of the effluent samples [11].

\subsection{EC (Electrical Conductivity)}

Electrical Conductivity was measured from effluent samples using conductivity meter (YSI Model 32) [11]. The EC meter was calibrated at $0.014 \mathrm{dS} / \mathrm{m}$ with $0.01 \mathrm{M} \mathrm{KCl}$ solution. 


\subsection{Ammonium-nitrogen}

Ammonium-nitrogen was determined by colorimetric methods [12]. After filtration with Whatman\#1, a portion of $4 \mathrm{ml}$ of effluent was taken into a $25 \mathrm{ml}$ test tube. Exactly 2 or 3 drops phenyl nitrophenol was added to the test tube. The absorbance of the sample was read at $420 \mathrm{~nm}$ using spectrophotometer (Shimadzu UV-1700 PharmaSpace) and the concentration of ammonium-nitrogen was obtained from a calibration curve. The standard curve was prepared with $0,1,2$, and $3 \mathrm{ppm} \mathrm{NH}_{4}{ }^{+}$solution.

\subsection{Phosphorus}

A portion of $4 \mathrm{ml}$ of effluent was taken into $25 \mathrm{ml}$ test tube after filtration with Whatman\#1. Exactly 6 $\mathrm{ml}$ of distilled water and $2 \mathrm{ml}$ of color reagent was added. The color reagent was prepared following [13]. Color regent was prepared by dissolving ascorbic acid in reagent $\mathrm{A}$. For reagent $\mathrm{A}$, dissolved $12 \mathrm{~g}$ of ammonium molybdate in $250 \mathrm{ml}$ of distilled water and also simultaneously dissolved $0.2908 \mathrm{~g}$ antimony potassium tartrate $\left(\mathrm{KSbO} \cdot \mathrm{C}_{4} \mathrm{H}_{4} \mathrm{O}_{6}\right)$ in $1000 \mathrm{ml}$ of $5 \mathrm{~N}$ $\mathrm{H}_{2} \mathrm{SO}_{4}$ (148 ml conc. $\mathrm{H}_{2} \mathrm{SO}_{4}$ per liter) and then mixed two solutions together thoroughly and made to volume $2000 \mathrm{ml}$ with distilled water. The absorbance of the sample was read at $710 \mathrm{~nm}$ using spectrophotometer (Shimadzu UV-1700 PharmaSpace) and the concentration of phosphorus was obtained from a calibration curve.

\subsection{Calcium and Magnesium}

Calcium and magnesium of effluent samples were determined directly with the help of an atomic absorption spectrophotometer (Hitachi 170-30) at 422.7 and $285.2 \mathrm{~nm}$ wavelengths respectively as outlined by [14].

\subsection{Sodium and Potassium}

Sodium and potassium of effluent samples were estimated with the help of flame photometer (Sherwood Flame Photometer 410) at $766.5 \mathrm{~nm}$ and $589 \mathrm{~nm}$ wavelengths, respectively as outlined by Page [14].

\subsection{Carbonate and Bicarbonate}

A portion of $5 \mathrm{ml}$ of effluent was taken into $25 \mathrm{ml}$ test tube after filtration with Whatman\#1. Then carbonate and bicarbonate of effluent samples were determined by titrating with $0.03 \mathrm{~N} \mathrm{HCl}$ using phenolphthalein and methyl orange as indicator for carbonate and bicarbonate, respectively [15].

\subsection{SAR (Sodium Adsorption ratio), SSP (Soluble Sodium Percentage)}

Irrigation water quality parameters viz., SAR and SSP were used to classify the suitability of waste water. The values of SAR and SSP were calculated using the following formula:

$$
\begin{gathered}
\text { SAR }=\frac{N a}{\sqrt{\frac{C a+M g}{2}}} \\
\mathrm{SSP}=\frac{\text { Soluble Na concentration }\left(\mathrm{meq}^{-1}\right)}{\text { Total cation concentration }\left(\mathrm{meq}^{-1}\right)} \times 100
\end{gathered}
$$

\subsection{Micronutrients and Heavy Metals}

Micronutrients (Fe, $\mathrm{Mn}, \mathrm{Cu}$ and $\mathrm{Zn}$ ) and Heavy metals (As, $\mathrm{Pb}, \mathrm{Cd}, \mathrm{Cr}$ and $\mathrm{Ni}$ ) of effluent samples were estimated directly with the help of atomic absorption spectrometer (Varian 55B) using acetylene gas [16].

The obtained data were statistically analyzed in IRRISTAT version 4.3 [17]. Analysis of correlations among for all possible combinations within the quality parameters and correlation between trace element and heavy metal concentrations of different industrial effluents were performed using a statistical software DPS (data processing system) developed by Tang [18].

\section{Results and Discussion}

\subsection{Effluent $p H$}

The $\mathrm{pH}$ of the tested water samples ranged from 
6.05 to 9.07 (Table 1). The beverage effluent had acidic reaction ( $\mathrm{pH}$ 6.05), which was about 1.2 unit lower than the control water. Polyvinyl industrial effluent had the similar $\mathrm{pH}$ as that of control water. Dyeing industry effluent had 0.20 and the mixed effluent had 0.25 unit higher $\mathrm{pH}$ than that of control water. The city waste water showed an increase in $\mathrm{pH}$ than control water by 0.37 unit. A remarkable increase in $\mathrm{pH}$ was found in the effluents of pharmaceuticals and tannery industries. The pharmaceutical effluent had $\mathrm{pH}$ of 8.55 and that in the tannery waste was 9.07.

Lower $\mathrm{pH}$ in the beverage effluent may be explained through the carbonate equilibrium. The beverage industry usually uses bicarbonate material which might have released some $\mathrm{CO}_{2}$ to the system that are responsible for producing $\mathrm{H}_{2} \mathrm{CO}_{3}$ and thus lowering $\mathrm{pH}$ of the effluent. Alkaline chemicals used in the pharmaceutical and tannery industries might have made their effluents too alkaline. Ayers [19] mentioned that normal $\mathrm{pH}$ range of irrigation water would vary from 6.0 to 8.5 . The $\mathrm{pH}$ value of tannery and pharmaceutical effluents were above the recommended range (6.0 to 8.5 ) meaning that these two were not suitable for irrigation. These findings are in good agreement with the findings of Tiwari and Begum [20, 21] where they reported that the higher $\mathrm{pH}$ of waste water was harmful for soils and rice crops.

\section{$3.2 E C$}

The EC of the tested effluent samples varied from 0.39 to $9.49 \mathrm{dS} \mathrm{m}^{-1}$ (Table 1). Control water contained the EC of $0.54 \mathrm{dS} / \mathrm{m}$. Polyvinyl effluent had 0.15 while beverage effluent had 0.10 unit lower EC content than that of control water. City waste water and MWW showed an increase in EC than the control water by 0.70 and 2.18 units, respectively. A remarkable increase in EC was found in the effluents of dyeing, pharmaceuticals and tannery industries. The tannery effluent had EC of $9.49 \mathrm{dS} / \mathrm{m}$ and that in the dyeing and pharmaceutical effluents were 4.30 and
$3.40 \mathrm{dS} / \mathrm{m}$, respectively. Higher EC in the tannery effluent may be explained through the sodium equilibrium. The tannery industry usually uses sodium salt for its processing which might have released some $\mathrm{Na}$ ions to the system that are responsible to high EC of the effluent.

Richards [22] categorized irrigation water into five salinity classes with respect to EC. On the basis of this classification, not a single sample was found excellent for irrigation and soil properties. Effluent samples such as polyvinyl, beverage including control were belonged to good class $\left(\mathrm{C}_{2}\right)$, CWW was in permissible class $\left(\mathrm{C}_{3}\right)$, mixed effluent was in doubtful class $\left(\mathrm{C}_{4}\right)$ and dyeing, pharmaceutical and tannery belonged to unsuitable class $\left(\mathrm{C}_{5}\right)$ indicating that these three effluents were hazardous in both rice crop and soil properties. These findings are at par with those of Tiwari and Kumer [20] where they reported that EC was higher in waste water than that of underground water.

\subsection{Ammonium Nitrogen}

Ammonium nitrogen of different effluent samples varied from 0.85 to $12.17 \mathrm{mg} \mathrm{L}^{-1}$ (Table 1). The lowest $\mathrm{NH}_{4}{ }^{+}-\mathrm{N}$ of $0.85 \mathrm{mg} \mathrm{L}^{-1}$ was obtained in underground control water. Polyvinyl industrial effluent had similar $\mathrm{NH}_{4}{ }^{+}-\mathrm{N}$ content $\left(0.85 \mathrm{mg} \mathrm{L}^{-1}\right)$ to that of control water. Dyeing industry effluent had 0.65 and pharmaceutical effluent had 0.56 unit higher $\mathrm{NH}_{4}{ }^{+} \mathrm{N}$ content than that of control water. The beverage effluent showed an increase in $\mathrm{NH}_{4}{ }^{+}-\mathrm{N}$ content than control water by 0.37 unit. A considerable amount of $\mathrm{NH}_{4}{ }^{+}-\mathrm{N}$ was found in CWW and mixed effluent which was 0.71 and 0.61units higher than that of control water. A considerable increase in $\mathrm{NH}_{4}{ }^{+}-\mathrm{N}$ was found in the tannery industries effluents. The tannery effluent had $\mathrm{NH}_{4}{ }^{+} \mathrm{N}$ content of $12.17 \mathrm{mg} \mathrm{L}^{-1}$. The highest $\mathrm{NH}_{4}{ }^{+}-\mathrm{N}$ content was found in tannery effluent because tannery had the source of protein which are in good agreement with the previous finding of Jahinger [23] (11.79 $\left.\mathrm{mg} \mathrm{L}^{-1}\right)$. 
Table 1 Chemical compositions (pH, EC, $\mathrm{NH}_{4}+-\mathrm{N}$ and effluent $\mathrm{P}$ ) of different industrial effluents.

\begin{tabular}{lllll}
\hline Types of effluents & $\mathrm{pH}$ & $\left.\mathrm{EC}(\mathrm{dS} \mathrm{m})^{-1}\right)$ & $\mathrm{NH}_{4}^{+}-\mathrm{N}\left(\mathrm{mg} \mathrm{L}^{-1}\right)$ & $\begin{array}{l}\text { Effluent P } \\
\left(\mathrm{mg} \mathrm{L}^{-1}\right)\end{array}$ \\
\hline Control & $7.24 \pm 0.08$ & $0.54 \pm 0.02$ & $0.85 \pm 0.004$ & $0.24 \pm 0.002$ \\
Polyvinyl & $7.25 \pm 0.03$ & $0.39 \pm 0.01$ & $0.85 \pm 0.01$ & $0.23 \pm 0.003$ \\
Dyeing & $7.45 \pm 0.01$ & $4.30 \pm 0.02$ & $1.5 \pm 0.01$ & $0.26 \pm 0.002$ \\
Pharmaceutical & $8.55 \pm 0.03$ & $3.40 \pm 0.02$ & $1.41 \pm 0.03$ & $0.31 \pm 0.005$ \\
Beverage & $6.05 \pm 0.02$ & $0.44 \pm 0.02$ & $1.19 \pm 0.01$ & $0.25 \pm 0.002$ \\
Tannery & $9.07 \pm 0.01$ & $9.49 \pm 0.10$ & $12.17 \pm 0.010$ & $0.26 \pm 0.002$ \\
City waste & $7.61 \pm 0.09$ & $1.24 \pm 0.003$ & $1.56 \pm 0.02$ & $0.27 \pm 0.004$ \\
Mixed (Cannel water) & $7.50 \pm 0.03$ & $2.72 \pm 0.01$ & $1.46 \pm 0.02$ & $0.27 \pm 0.002$ \\
CV (\%) & 1.10 & 2.30 & 2.40 & 1.60 \\
\hline
\end{tabular}

\subsection{Effluent $P$}

The $\mathrm{P}$ content of the tested water samples ranged from 0.23 to $0.31 \mathrm{mg} \mathrm{L}^{-1}$ (Table 1). The P content of $0.24 \mathrm{mg} \mathrm{L}^{-1}$ was found in control water. The similar $\mathrm{P}$ content $\left(0.23 \mathrm{mg} \mathrm{L}^{-1}\right)$ was found in polyvinyl effluent as that obtained in control water. Dyeing industry effluent had 0.02 unit higher $\mathrm{P}$ content than that of control water. Beverage, tannery, CWW and mixed effluent gave similar $\mathrm{P}$ content as that of dyeing effluent. The highest $\mathrm{P}$ content of $0.31 \mathrm{mg} \mathrm{L}^{-1}$ was found in pharmaceutical effluent which was 0.07 unit higher than control water. The maximum permissible limit of $\mathrm{P}$ content in irrigation water is $2.00 \mathrm{mg} \mathrm{L}^{-1}$ [24]. Therefore, all the effluent samples were suitable for irrigation with respect to phosphorus content.

\subsection{Sodium}

The Na concentration among the different effluent samples ranged from 7 to $1,200 \mathrm{mg} \mathrm{L}^{-1}$ (Table 2). The lowest Na content of $7 \mathrm{mg} \mathrm{L}^{-1}$ was obtained in control water. Polyvinyl industrial effluent recorded 20 unit higher $\mathrm{Na}$ content than control water. Beverage effluent gave the similar Na content $\left(27 \mathrm{mg} \mathrm{L}^{-1}\right)$ as that of the polyvinyl effluent. Dyeing industry effluent had about 30 and pharmaceutical effluent had 50 folds higher Na content than control water. A considerable amount of Na content was found in CWW and MWW which was about 29 and 25 folds higher than control water. A remarkable increase in Na content was found in the effluents of tannery industries. The highest $\mathrm{Na}$ content of $1200 \mathrm{mg} \mathrm{L}^{-1}$ was found in tannery effluent. The tannery industry usually uses sodium salt for its processing which might have released some $\mathrm{Na}$ ions to the system that are responsible for the higher $\mathrm{Na}$ content on its effluent. This result is in good support with the earlier finding of Hussain [25] (1,070 mg L').

\subsection{Potassium}

The $\mathrm{K}$ content of the tested water samples ranged from 2 to $34 \mathrm{mg} \mathrm{L}^{-1}$ (Table 2). The lowest $\mathrm{K}$ content of $2 \mathrm{mg} \mathrm{L}^{-1}$ was obtained in control water. Polyvinyl and beverage industrial effluents gave similar $\mathrm{K}$ content $\left(2 \mathrm{mg} \mathrm{L}^{-1}\right)$ as that of control water. Dyeing, tannery effluents and MWW showed an increase in K content than control water by 3, 11 and 9 units, respectively. City waste water had similar K content $\left(13 \mathrm{mg} \mathrm{L}^{-1}\right)$ as that of tannery effluent. A remarkable increase in $\mathrm{K}$ content was found in the pharmaceutical industries effluents. The pharmaceutical effluent gave the higher $\mathrm{K}$ content of $34 \mathrm{mg} \mathrm{L}^{-1}$ which is similar to the previous result that obtained by Osaigbovo [26] (38.86 mg L ${ }^{-1}$ ).

High $\mathrm{K}$ content in the water is an advantage with respect to plant nutrition as long as the water is not hazardous with Na or heavy metals. Potassiun content of $1 \mathrm{mg} \mathrm{L}^{-1}$ in irrigation water adds about $1 \mathrm{~kg} \mathrm{ha}^{-1} \mathrm{~K}$ at every $10 \mathrm{~cm}$ of application. Application of $10 \mathrm{~cm}$ irrigation with the CWW would supply about $13 \mathrm{~kg}$ of $\mathrm{K}$ per ha, which is more than requirement by a rice crop that requires 10-12 irrigation per season. 
Table 2 Chemical compositions $\left(\mathrm{Na}^{+}, \mathrm{K}^{+}, \mathrm{Ca}^{2+}\right.$ and $\left.\mathrm{Mg}^{2+}\right)$ of different industrial effluents.

\begin{tabular}{lllcc}
\hline \multirow{2}{*}{ Types of effluents } & $\mathrm{Na}^{+}$ & $\mathrm{K}^{+}$ & $\mathrm{Ca}^{2+}$ & $\mathrm{Mg}^{2+}$ \\
\cline { 2 - 4 } & & $2 \pm 0.0$ & $14 \pm 0.11$ & $12 \pm 0.11$ \\
\hline Control & $7 \pm 0.0$ & $2 \pm 0.0$ & $15 \pm 0.19$ & $12 \pm 0.22$ \\
Polyvinyl & $27 \pm 0.0$ & $5 \pm 0.0$ & $29 \pm 0.51$ & $16 \pm 0.20$ \\
Dyeing & $213 \pm 0.0$ & $34 \pm 0.5$ & $56 \pm 1.23$ & $30 \pm 1.39$ \\
Pharmaceutical & $350 \pm 0.0$ & $2 \pm 0.0$ & $14 \pm 0.22$ & $10 \pm 0.47$ \\
Beverage & $27 \pm 0.0$ & $13 \pm 0.0$ & $61 \pm 0.77$ & $34 \pm 0.45$ \\
Tannery & $1200 \pm 0.0$ & $13 \pm 0.0$ & $38 \pm 0.59$ & $15 \pm 0.47$ \\
City waste & $205 \pm 0.0$ & $11 \pm 0.0$ & $42 \pm 0.38$ & $13 \pm 1.76$ \\
Mixed (Cannel water) & $173 \pm 0.0$ & 3.00 & 3.00 & 8.00 \\
CV (\%) & 4.00 & &
\end{tabular}

\subsection{Calcium}

The Ca concentration of industrial effluent samples was within the range of 14 to $61 \mathrm{mg} \mathrm{L}^{-1}$ (Table 2). Control water contained the lowest Ca content of 14 $\mathrm{mg} \mathrm{L}^{-1}$. Polyvinyl and beverage effluent gave similar Ca content to that of control water. The dyeing industry effluent showed an increase in Ca content than the control water by 15 unit. City waste water had 24 and mixed effluent effluent had 28 unit higher Ca content than that of control water. A remarkable increase in $\mathrm{Ca}$ content was found in the pharmaceuticals and tannery industries effluents. The pharmaceutical effluent had Ca content of 56 and that

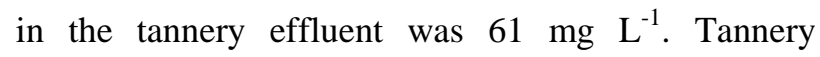
effluent contained the highest amount of Ca content because of it higher $\mathrm{pH}$ and $\mathrm{EC}$ value. A similar $\mathrm{Ca}$ content in tannery effluent $\left(60 \mathrm{mg} \mathrm{L}^{-1}\right)$ was reported by Hussain [25]. Irrigation water usually contained less than $100 \mathrm{mg} \mathrm{L}^{-1}$ calcium [27]. Therefore, all the effluent samples were suitable for irrigation with respect to calcium content.

\subsection{Magnesium}

The Mg content of the tested water samples ranged from $10 \mathrm{mg} \mathrm{L}^{-1}$ to $34 \mathrm{mg} \mathrm{L}^{-1}$ (Table 2). Control water had the Mg content of $12 \mathrm{mg} \mathrm{L}^{-1}$. Polyvinyl effluent had the similar Mg content to that of control water. Dyeing industry effluent had 4 unit higher Mg content than that of control water. Pharmaceutical effluent gave 18 higher while beverage effluent gave 2 units lower Mg content than that of control water. City waste water contained the similar Mg content to that of dyeing effluent. Mixed effluent had almost the similar Mg content to that of control water. The maximum $\mathrm{Mg}$ content of $34 \mathrm{mg} \mathrm{L}^{-1}$ was found in tannery effluent. It might be due use of $\mathrm{Mg}$ salt for tannery processing like $\mathrm{Na}$ salt and also higher $\mathrm{pH}$ and EC values. Hussain [25] showed that the tannery effluent was rich in Mg. Todd [27] reported that irrigation water usually contained $50 \mathrm{mg} \mathrm{L}^{-1} \mathrm{Mg}$ and accordingly the effluents samples of all industries were suitable for irrigation in agriculture with respect to magnesium.

\subsection{Carbonate $\left(\mathrm{CO}_{3}{ }^{\circ}\right)$ and bicarbonate $\left(\mathrm{HCO}_{3}{ }^{-}\right)$}

Carbonate content of different effluent samples varied from 0.18 to $1.56 \mathrm{~g} \mathrm{~L}^{-1}$ (Table 3). Control water had the $\mathrm{CO}_{3}{ }^{=}$content of $0.30 \mathrm{~g} \mathrm{~L}^{-1}$. Polyvinyl effluent had 0.09 and beverage effluent had 0.12 unit and lower $\mathrm{CO}_{3}{ }^{=}$content than that of control water. The dyeing industry effluent increased in $\mathrm{CO}_{3}{ }^{2}$ content than the control water by 18 unit. City waste water had 0.30 and mixed effluent had 0.28 unit higher $\mathrm{CO}_{3}{ }^{=}$ content than that of control water. A considerable amount of $\mathrm{CO}_{3}{ }^{=}$content was found in the pharmaceuticals and tannery industries effluents. The pharmaceutical effluent had $\mathrm{CO}_{3}{ }^{=}$content of $0.93 \mathrm{~g} \mathrm{~L}^{-1}$ and that in the tannery effluent was $1.56 \mathrm{~g} \mathrm{~L}^{-1}$. Bohn 
Table 3 Chemical compositions $\left(\mathrm{CO}_{3}{ }^{-}\right.$and $\left.\mathrm{HCO}_{3}{ }^{-}\right)$and computed parameters (SAR and SSP) of different industrial effluents.

\begin{tabular}{|c|c|c|c|c|}
\hline \multirow{2}{*}{ Types of effluents } & $\mathrm{CO}_{3}{ }^{=}$ & $\mathrm{HCO}_{3}^{-}$ & SAR & SSP \\
\hline & \multicolumn{2}{|c|}{-----------g L ${ }^{-1}$---------- } & \multicolumn{2}{|c|}{ 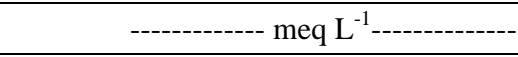 } \\
\hline Control & $0.30 \pm 0.03$ & $1.46 \pm 0.00$ & $2 \pm 0.01$ & $20 \pm 0.15$ \\
\hline Polyvinyl & $0.21 \pm 0.03$ & $1.01 \pm 0.05$ & $7 \pm 0.02$ & $47 \pm 0.16$ \\
\hline Dyeing & $0.48 \pm 0.03$ & $2.10 \pm 0.05$ & $47 \pm 0.31$ & $84 \pm 0.18$ \\
\hline Pharmaceutical & $0.93 \pm 0.03$ & $3.81 \pm 0.08$ & $53 \pm 0.73$ & $80 \pm 0.43$ \\
\hline Beverage & $0.18 \pm 0.00$ & $1.09 \pm 0.05$ & $8 \pm 0.07$ & $53 \pm 0.42$ \\
\hline Tannery & $1.56 \pm 0.06$ & $7.87 \pm 0.21$ & $175 \pm 0.33$ & $93 \pm 0.03$ \\
\hline City waste & $0.60 \pm 0.03$ & $2.50 \pm 0.03$ & $40 \pm 0.32$ & $79 \pm 0.26$ \\
\hline Mixed (Cannel water) & $0.48 \pm 0.03$ & $1.77 \pm 0.61$ & $33 \pm 0.63$ & $76 \pm 0.70$ \\
\hline CV (\%) & 9.80 & 14.90 & 2.00 & 1.00 \\
\hline
\end{tabular}

[28] reported that the concentration of $\mathrm{CO}_{3}{ }^{=}$should be negligible at $\mathrm{pH}$ below 9.0. It might be the reason of low carbonate content as because the $\mathrm{pH}$ values of all effluents were less than 9.0 except tannery effluent. A similar finding was also reported by Begum [21].

Bicarbonate content of the tested water samples ranged from 1.01 to $7.87 \mathrm{~g} \mathrm{~L}^{-1}$ (Table 3). Control water had the $\mathrm{HCO}_{3}{ }^{-}$content of $1.46 \mathrm{~g} \mathrm{~L}^{-1}$. Polyvinyl effluent contained 0.45 and beverage effluent contained 0.37 unit lower $\mathrm{HCO}_{3}{ }^{-}$content than that of control water. Dyeing industry effluent tended to increase in $\mathrm{HCO}_{3}{ }^{-}$content than the control water by 0.64 unit. City waste water had 1.04 and mixed effluent had 0.31 unit higher $\mathrm{HCO}_{3}{ }^{-}$content than that control water. A remarkable increase in $\mathrm{HCO}_{3}{ }^{-}$was found in the pharmaceuticals and tannery industries effluents. The pharmaceutical effluent had $\mathrm{HCO}_{3}{ }^{-}$ content of $3.81 \mathrm{~g} \mathrm{~L}^{-1}$ and that in the tannery effluent was $7.87 \mathrm{~g} \mathrm{~L}^{-1}$ which was higher than the value (4.32 $\mathrm{g} \mathrm{L}^{-1}$ ) reported by Hussain [25]. As the amount of $\mathrm{HCO}_{3}{ }^{-}$content was more in pharmaceutical and tannery effluents indicates that these two effluents contained residual sodium carbonate.

\subsection{SAR and SSP}

Sodium adsorption ratio of the tested water samples ranged from 2 to 175 meq $L^{-1}$ (Table 3). The control water had the lowest SAR of 2 meq $\mathrm{L}^{-1}$. Polyvinyl effluent had 5 unit higher SAR than that of control water. Beverage industry effluent had almost similar SAR to that of polyvinyl effluent. The dyeing industry effluent had 24 and pharmaceutical effluent had 26 folds higher SAR than that of control water. City waste water and mixed effluent tended to increase in SAR than the control water by 20 and 16 folds, respectively. A remarkable increase in SAR was found in the tannery industry effluent. The tannery effluent had SAR of 175 meq $\mathrm{L}^{-1}$. With respect to SAR, no effluent samples were graded as excellent or good. In this regard, alkalinity problem might occur due to irrigation with above mentioned effluents.

Soluble sodium percentage of the tested water samples varied from 20 meq $\mathrm{L}^{-1}$ to 93 meq $\mathrm{L}^{-1}$ (Table $3)$. The lowest SSP of 20 meq $L^{-1}$ was obtained in control water. Polyvinyl effluent had 27 unit higher SSP value than that of control water. Beverage industry effluent had almost the similar SSP to that of polyvinyl effluent. Both in dyeing and pharmaceutical industry effluents had about 4 folds higher SSP than that of control water. City waste water and mixed effluent showed almost the similar SSP to that of pharmaceutical effluent. The tannery effluent had the highest SSP of $93 \mathrm{meq} \mathrm{L}^{-1}$. Soluble sodium percentage values of the effluent samples were not satisfactory for irrigation uses. According to Wilcox [29], tannery, dyeing and pharmaceutical effluents were strictly unsuitable, CWW and MWW were doubtful, polyvinyl and beverage were permissible and control 
was considered good for crop production and soil properties. Effluents under unsuitable and doubtful category might affect plant growth and soil physical properties [30]). Sodium toxicity would adversely affect plant development, vegetative and shoot growth as well as root growth stage by reducing cell elongation [31, 32].

\subsection{Micronutrients (Fe, $\mathrm{Zn}, \mathrm{Mn}$ and $\mathrm{Cu}$ )}

The micronutrients (Fe, Zn, Mn and $\mathrm{Cu}$ ) concentration of different industrial effluents varied significantly (Table 4). Iron ( $\mathrm{Fe}$ ) content of the tested effluent samples ranged from 2.09 to $8.03 \mathrm{mg} \mathrm{L}^{-1}$. Ahmed [33] showed that the Fe content in different effluents ranged from 4.13 to $5.53 \mathrm{mg} \mathrm{L}^{-1}$. The control water contained the lowest Fe content of $2.09 \mathrm{mg} \mathrm{L}^{-1}$. Polyvinyl effluent had similar Fe content to that of control water. The dyeing effluent had 1.94 and beverage effluent had 1.0 units higher Fe content than that of control water. City waste water and mixed effluent increased in Fe content than the control water by 1.40 and 1.64 units, respectively. A remarkable increase in Fe content was found in the pharmaceuticals and tannery industries effluents. The pharmaceutical effluent had Fe content of $8.03 \mathrm{mg} \mathrm{L}^{-1}$ and that in the tannery effluent was $6.83 \mathrm{mg} \mathrm{\textrm {L } ^ { - 1 }}$. The maximum permissible limit of Fe content in irrigation water is $5.00 \mathrm{mg} \mathrm{L}^{-1}$ [19]. From this, it is evident that all the samples except pharmaceutical and tannery effluents were suitable for irrigation with respect to Fe content.
Zinc (Zn) content of different effluent samples ranged from $0.14 \mathrm{mg} \mathrm{L}^{-1}$ to $2.11 \mathrm{mg} \mathrm{L}^{-1}$ (Table 4) which was almost similar to the values $(0.49-1.69 \mathrm{mg}$ $\mathrm{L}^{-1}$ ) reported by Ahmed [33]. The control water gave Zn content of $0.20 \mathrm{mg} \mathrm{L}^{-1}$. Polyvinyl effluent had the equal $\mathrm{Zn}$ content to that of control water. Dyeing effluent had 0.85 higher while beverage effluent had 0.06 units lower $\mathrm{Zn}$ content than that of control water. City waste water and mixed effluent increased in $\mathrm{Zn}$ content than the control water by 1.29 and 0.89 units, respectively. A remarkable increase in $\mathrm{Zn}$ content was found in the pharmaceuticals and tannery industries effluents. The pharmaceutical effluent had $\mathrm{Zn}$ content of $2.03 \mathrm{mg} \mathrm{L}^{-1}$ while in tannery effluent it was $2.11 \mathrm{mg} \mathrm{L^{-1 }}$. Ayers [19] reported that the maximum permissible limit of $\mathrm{Zn}$ content in irrigation water is $2.00 \mathrm{mg} \mathrm{L}^{-1}$. It is therefore, evident that all the samples except pharmaceutical and tannery effluents were suitable for irrigation with respect to $\mathrm{Zn}$ content.

The Mn content of the tested water samples varied from $0.14 \mathrm{mg} \mathrm{L}^{-1}$ to $1.80 \mathrm{mg} \mathrm{L}^{-1}$ (Table 4). The control water had Mn content of $0.16 \mathrm{mg} \mathrm{L}^{-1}$. Polyvinyl effluent had 0.10 unit higher Mn content than that of control water. Dyeing effluent had 0.31 higher and beverage effluent had 0.02 unit lower Mn content than that of control water. City waste water and mixed effluent gave almost the similar Mn content to that of dyeing effluent. A noticeable increase in Mn content was found in the pharmaceuticals and tannery

Table 4 Micronutrients (Fe, $\mathrm{Zn}, \mathrm{Mn}$ and $\mathrm{Cu}$ ) constituents of different industrial effluents.

\begin{tabular}{lllll}
\hline \multirow{2}{*}{ Types of effluents } & \multicolumn{3}{c}{ Trace elements $\left(\mathrm{mg} \mathrm{L}^{-1}\right)$} \\
\cline { 2 - 5 } & $\mathrm{Fe}$ & $\mathrm{Zn}$ & $\mathrm{Mn}$ & $\mathrm{Cu}$ \\
\hline Control & $2.09 \pm 0.0$ & $0.20 \pm 0.0$ & $0.16 \pm 0.0$ & $0.11 \pm 0.0$ \\
Polyvinyl & $2.09 \pm 0.0$ & $0.20 \pm 0.0$ & $0.26 \pm 0.0$ & $0.14 \pm 0.004$ \\
Dyeing & $4.03 \pm 0.0$ & $1.05 \pm 0.04$ & $0.47 \pm 0.02$ & $0.73 \pm 0.02$ \\
Pharmaceutical & $8.03 \pm 0.03$ & $2.03 \pm 0.02$ & $1.80 \pm 0.02$ & $1.20 \pm 0.01$ \\
Beverage & $3.09 \pm 0.02$ & $0.14 \pm 0.007$ & $0.14 \pm 0.01$ & $0.16 \pm 0.006$ \\
Tannery & $6.83 \pm 0.03$ & $2.11 \pm 0.02$ & $1.59 \pm 0.02$ & $0.94 \pm 0.01$ \\
City waste & $3.49 \pm 0.02$ & $1.49 \pm 0.02$ & $0.45 \pm 0.02$ & $0.68 \pm 0.01$ \\
Mixed (Cannel water) & $3.73 \pm 0.02$ & $1.09 \pm 0.003$ & $0.53 \pm 0.01$ & $0.58 \pm 0.01$ \\
CV (\%) & 1.00 & 3.20 & 3.50 & 2.70 \\
\hline
\end{tabular}


industries effluents. The pharmaceutical effluent had Mn content of $1.80 \mathrm{mg} \mathrm{L}^{-1}$ while in tannery effluent it was $1.59 \mathrm{mg} \mathrm{L}^{-1}$. According to Ayers [19] the maximum permissible limit of $\mathrm{Mn}$ content in irrigation water is $0.20 \mathrm{mg} \mathrm{L}^{-1}$. Thus, only beverage effluent was suitable for irrigation with respect to $\mathrm{Mn}$ content.

Copper $(\mathrm{Cu})$ content of different effluents ranged from 0.11 to $1.2 \mathrm{mg} \mathrm{L}^{-1}$ (Table 4) which was lower than the values (1.35- $2.88 \mathrm{mg} \mathrm{L}^{-1}$ ) reported by [33]. Control water contained the lowest $\mathrm{Cu}$ content of 0.11 $\mathrm{mg} \mathrm{L}^{-1}$. Polyvinyl effluent had 0.02 unit higher $\mathrm{Cu}$ content than that of control water. Dyeing effluent had 0.62 and beverage had 0.04 unit higher $\mathrm{Cu}$ content than that of control water. City waste water and mixed effluent tended to increase in $\mathrm{Cu}$ content than the control water by 0.57 and 0.47 units, respectively. A considerable increase in $\mathrm{Cu}$ content was found in the pharmaceuticals and tannery industries effluents. The pharmaceutical effluent had Cu content of $1.20 \mathrm{mg} \mathrm{L}^{-1}$ and that in the tannery effluent was $0.94 \mathrm{mg} \mathrm{L}^{-1}$. The maximum permissible limit of $\mathrm{Cu}$ content in irrigation water is $0.20 \mathrm{mg} \mathrm{L}^{-1}$ [19]. In this regard polyvinyl and beverage industrial effluents were suitable for irrigation.

\subsection{Heavy metals (As, $\mathrm{Pb}, \mathrm{Cd}, \mathrm{Cr}$ and $\mathrm{Ni}$ )}

Arsenic content of the effluent samples varied from 0.005 to $0.008 \mathrm{mg} \mathrm{L}^{-1}$ (Table 5). The lowest As content of $0.005 \mathrm{mg} \mathrm{L}^{-1}$ was found in control water. Beverage effluent had the equal As content to that of control water. Dyeing effluent had 0.001 unit higher As content than that of control water. Pharmaceutical and tannery effluents had the equal As content to that of control. Both CWW and and mixed effluent tended to increase in As content than the control water by 0.002 unit. The highest As content of $0.008 \mathrm{mg} \mathrm{L}^{-1}$ was found in polyvinyl effluent. According to Ayers [19] the maximum permissible limit of As content in irrigation water is $0.01 \mathrm{mg} \mathrm{L}^{-1}$. From this, all the effluent samples were suitable for irrigated agriculture with respect to As content.

The $\mathrm{Pb}$ concentration of the tested water samples ranged from 0.06 to $4.29 \mathrm{mg} \mathrm{L}^{-1}$ (Table 5) which was higher than the values $\left(0.14-0.30 \mathrm{mg} \mathrm{L}^{-1}\right)$ reported by Ahmed [33]. Control water contained the $\mathrm{Pb}$ content of $0.13 \mathrm{mg} \mathrm{L}^{-1}$. Polyvinyl had 0.04 and beverage had 0.07 unit lower $\mathrm{Pb}$ content than that of control water. Dyeing effluent increased in $\mathrm{Pb}$ content than the control water by 2.38 unit. A noticeable increase in $\mathrm{Pb}$ content was found in the pharmaceuticals, tannery, CWW and mixed effluent. The $\mathrm{Pb}$ content of 4.29, 3.94, 3.04 and $4.01 \mathrm{mg} \mathrm{L}^{-1}$ were found in pharmaceutical, tannery, CWW and mixed effluent, respectively. Ayers [19] reported that the maximum permissible limit of $\mathrm{Pb}$ content in irrigation water is $5.00 \mathrm{mg} \mathrm{L}^{-1}$. Thus, the experimental results revealed that all the effluent samples were suitable for irrigation with respect to $\mathrm{Pb}$ content. This result was in good agreement with the previous result of Begum [21].

The concentration of cadmium (Cd) in different industrial effluent samples varied from 0.001 to 0.018 $\mathrm{mg} \mathrm{L}^{-1}$ (Table 5) which was lower than the values (0.02- $0.08 \mathrm{mg} \mathrm{L}^{-1}$ ) reported by Ahmed [33]. Control water contained the lowest Cd content of $0.001 \mathrm{mg} \mathrm{L}^{-1}$. Polyvinyl had 0.005 unit higher Cd content than that of control water. Dyeing and pharmaceutical effluents increased in Cd content than the control water by 0.013 and 0.014 units, respectively. Beverage effluent had 0.008 unit higher Cd content than that of control water. City waste water and mixed effluent had almost equal Cd content to that of control water. A noticeable increase in Cd content was found in the tannery effluent. The tannery effluent contained Cd content of $0.018 \mathrm{mg} \mathrm{L}^{-1}$. Ayers [19] reported that the maximum permissible limit of $\mathrm{Cd}$ content in irrigation water is $0.01 \mathrm{mg} \mathrm{L}^{-1}$. In this regard all the effluent samples were suitable for irrigated agriculture except tannery effluent.

The Cr content of the tested effluent samples ranged from 0.003 to $0.38 \mathrm{mg} \mathrm{L}^{-1}$ (Table 5) which was lower 
Table 5 Heavy metals (As, Pb, Cd, Cr and Ni) constituents of different industrial effluents.

\begin{tabular}{llllll}
\hline \multirow{2}{*}{ Types of effluents } & \multicolumn{5}{c}{ Heavy metals $\left(\mathrm{mg} \mathrm{L}^{-1}\right)$} \\
\cline { 2 - 6 } & $\mathrm{As}$ & $\mathrm{Pb}$ & $\mathrm{Cd}$ & $\mathrm{Cr}$ & $\mathrm{Ni}$ \\
\hline Control & $0.005 \pm 0.0002$ & $0.13 \pm 0.006$ & $0.001 \pm 0.0$ & $0.003 \pm 0.0003$ & $0.03 \pm 0.003$ \\
Polyvinyl & $0.008 \pm 0.0005$ & $0.10 \pm 0.006$ & $0.006 \pm 0.0$ & $0.03 \pm 0.001$ & $0.08 \pm 0.002$ \\
Dyeing & $0.006 \pm 0.0003$ & $2.51 \pm 0.02$ & $0.013 \pm 0.0006$ & $0.15 \pm 0.002$ & $0.25 \pm 0.006$ \\
Pharmaceutical & $0.006 \pm 0.0004$ & $4.29 \pm 0.006$ & $0.014 \pm 0.0006$ & $0.14 \pm 0.002$ & $0.24 \pm 0.009$ \\
Beverage & $0.005 \pm 0.0001$ & $0.06 \pm 0.006$ & $0.009 \pm 0.0003$ & $0.02 \pm 0.001$ & $0.03 \pm 0.003$ \\
Tannery & $0.006 \pm 0.0001$ & $3.94 \pm 0.03$ & $0.018 \pm 0.0006$ & $0.38 \pm 0.004$ & $0.16 \pm 0.006$ \\
City waste & $0.007 \pm 0.0001$ & $3.04 \pm 0.04$ & $0.009 \pm 0.0003$ & $0.05 \pm 0.002$ & $0.11 \pm 0.006$ \\
Mixed (Cannel water) & $0.007 \pm 0.0004$ & $4.01 \pm 0.04$ & $0.010 \pm 0.003$ & $0.09 \pm 0.002$ & $0.12 \pm 0.003$ \\
CV (\%) & 8.50 & 6.90 & 6.90 & 2.70 & 7.10 \\
\hline
\end{tabular}

than the values $\left(0.29-0.53 \mathrm{mg} \mathrm{L}^{-1}\right)$ reported by Ahmed [33]. Control water had the lowest $\mathrm{Cr}$ content of $0.003 \mathrm{mg} \mathrm{L}^{-1}$. Polyvinyl effluent had 0.027 unit higher $\mathrm{Cr}$ content than that of control water. Beverage effluent had 0.017 unit higher $\mathrm{Cr}$ content than that of control water. City waste water and mixed effluent showed an increase in $\mathrm{Cr}$ content than the control water by 0.047 and 0.087 units, respectively. A remarkable increase in $\mathrm{Cr}$ content was found in the dyeing, pharmaceutical and tannery effluents. The $\mathrm{Cr}$ content of $0.15,0.14$ and $0.38 \mathrm{mg} \mathrm{L}^{-1}$ were found in dyeing, pharmaceutical and tannery industries effluents, respectively. According to Ayers [19] the maximum permissible limit of $\mathrm{Cr}$ content in irrigation water is $0.10 \mathrm{mg} \mathrm{L}^{-1}$. Thus, the effluent samples of dyeing, pharmaceutical and tannery were unsuitable for irrigated agriculture with respect to Cr content.

The Ni content of the tested different industrial effluent samples varied from 0.03 to $0.25 \mathrm{mg} \mathrm{L}^{-1}$ (Table 5) which was lower than the values (0.13-0.29 $\mathrm{mg} \mathrm{L}^{-1}$ ) reported by [33]. Control water gave the $\mathrm{Ni}$ content of $0.03 \mathrm{mg} \mathrm{L}^{-1}$. Beverage effluent had the similar Ni content to that of control water. Polyvinyl effluent had 0.05 unit higher $\mathrm{Ni}$ content to that of control water. Tannery effluent, CWW and mixed effluent showed an increase in $\mathrm{Ni}$ content than the control water by $0.13,0.08$ and 0.09 unit, respectively. A remarkable increase in Ni content was found in the dyeing and pharmaceutical effluents. The dyeing effluent had Ni content of $0.25 \mathrm{mg} \mathrm{L}^{-1}$ and that in the pharmaceutical effluent was $0.24 \mathrm{mg} \mathrm{L}^{-1}$. The maximum permissible limit of $\mathrm{Ni}$ content in irrigation water is $0.20 \mathrm{mg} \mathrm{L}^{-1}$ [19]. From this, the effluent samples of dyeing and pharmaceutical were not suitable for irrigated agriculture with respect to $\mathrm{Ni}$ content.

\subsection{Correlation Coefficient Analysis}

Correlation coefficient analysis was performed the effluent parameters viz., pH, EC, Na, K, Ca, Mg, SAR and SSP in all possible combination (Table 6). It was evident that $\mathrm{pH}$ value was significantly correlated with EC, Na, Ca, Mg, SAR and SSP at $1 \%$ level of significance but had no effect on $\mathrm{K}$ value. EC value was significantly correlated with $\mathrm{Na}, \mathrm{Ca}, \mathrm{Mg}, \mathrm{SAR}$ and SSP values. It indicated that EC influence on $\mathrm{Na}$, $\mathrm{Ca}, \mathrm{Mg}, \mathrm{SAR}$ and SSP values. Na showed significant positive correlation with $\mathrm{Ca}, \mathrm{Mg}$, SAR and SSP. On the other hand $\mathrm{K}$ had no relation with the tested parameters. Ca had significant correlation with Mg, SAR and SSP. Mg showed close relationship with SAR and SSP. SAR had also significant interrelation with SSP at $1 \%$ level of significance.

Correlation between micronutrients ( $\mathrm{Fe}, \mathrm{Zn}, \mathrm{Mn}$, $\mathrm{Cu}$ ) and heavy metals (As, Pb, Cd, Cr, Ni) concentration of different industrial effluents was shown in Table 7. A significant positive correlation was found among $\mathrm{Fe}, \mathrm{Zn}, \mathrm{Mn}, \mathrm{Cu}, \mathrm{Pb}, \mathrm{Cd}, \mathrm{Cr}$ and $\mathrm{Ni}$. 
Table 6 Correlations matrix among the different parameters of industrial effluents.

\begin{tabular}{lllllllll}
\hline & $\mathrm{pH}$ & $\mathrm{EC}$ & $\mathrm{Na}^{+}$ & $\mathrm{K}^{+}$ & $\mathrm{Ca}^{2+}$ & $\mathrm{Mg}^{2+}$ & $\mathrm{SAR}$ & $\mathrm{SSP}$ \\
\hline $\mathrm{pH}$ & 1 & & & & & & \\
$\mathrm{EC}$ & $0.733^{* *}$ & 1 & & & & & \\
$\mathrm{Na}^{+}$ & $0.812^{* *}$ & $0.953^{* *}$ & 1 & & & & \\
$\mathrm{~K}^{+}$ & $0.133 \mathrm{~ns}$ & -0.269 & -0.033 & 1 & & & \\
$\mathrm{Ca}^{2+}$ & $0.883^{* *}$ & $0.781^{* *}$ & $0.789^{* *}$ & $0.048 \mathrm{~ns}$ & 1 & & \\
$\mathrm{Mg}^{2+}$ & $0.905^{* *}$ & $0.825^{* *}$ & $0.859^{* *}$ & $0.133 \mathrm{~ns}$ & $0.871^{* *}$ & 1 & & \\
$\mathrm{SAR}$ & $0.809^{* *}$ & $0.968^{* *}$ & $0.995^{* *}$ & -0.111 & $0.800^{* *}$ & $0.846^{* *}$ & 1 & \\
SSP & $0.601^{* *}$ & $0.711^{* *}$ & $0.643^{* *}$ & -0.450 & $0.820^{* *}$ & $0.611^{* *}$ & $0.697^{* *}$ & 1 \\
\hline
\end{tabular}

ns and $* *$ represent non significant and highly significant at $1 \%$ probability, respectively.

Table 7 Correlation between trace elements and heavy metal concentrations of different industrial effluents

\begin{tabular}{|c|c|c|c|c|c|c|c|c|c|}
\hline & $\mathrm{Fe}$ & $\mathrm{Zn}$ & Mn & $\mathrm{Cu}$ & As & $\mathrm{Pb}$ & $\mathrm{Cd}$ & $\mathrm{Cr}$ & $\mathrm{Ni}$ \\
\hline $\mathrm{Fe}$ & 1 & & & & & & & & \\
\hline $\mathrm{Zn}$ & $0.889 * *$ & 1 & & & & & & & \\
\hline Mn & $0.976 * *$ & $0.887 * *$ & 1 & & & & & & \\
\hline $\mathrm{Cu}$ & $0.923 * *$ & $0.962 * *$ & $0.888 * *$ & 1 & & & & & \\
\hline As & -0.136 & $0.096 \mathrm{~ns}$ & -0.032 & $0.046 \mathrm{~ns}$ & 1 & & & & \\
\hline $\mathrm{Pb}$ & $0.786 * *$ & $0.927 * *$ & $0.764 * *$ & $0.916 * *$ & $0.187 \mathrm{~ns}$ & 1 & & & \\
\hline Cd & $0.833^{* *}$ & $0.818^{* *}$ & $0.777 * *$ & $0.829 * *$ & $0.026 \mathrm{~ns}$ & $0.756^{* *}$ & 1 & & \\
\hline $\mathrm{Cr}$ & $0.738 * *$ & $0.764 * *$ & $0.765 * *$ & $0.691 * *$ & -0.044 & $0.645^{* *}$ & $0.861 * *$ & 1 & \\
\hline $\mathrm{Ni}$ & $0.724 * *$ & $0.728 * *$ & $0.671^{* *}$ & $0.860 * *$ & $0.122 \mathrm{~ns}$ & $0.727 * *$ & $0.734 * *$ & $0.567 * *$ & 1 \\
\hline
\end{tabular}

ns and $* *$ represent non significant and highly significant at $1 \%$ probability, respectively.

In contrast, as had no correlation either trace elements or other heavy metals. It showed either negative or non significant correlation with trace elements or heavy metals.

\section{Conclusions}

Among the effluents, polyvinyl, beverage industrials effluents and city waste water may be used for irrigation in considering $\mathrm{pH}, \mathrm{EC}, \mathrm{SAR}, \mathrm{SSP}$ and heavy metals contents such as $\mathrm{Cu}, \mathrm{Pb}, \mathrm{Cr}, \mathrm{Cd}$, As and Ni. Tannery, dyeing, pharmaceutical effluents could not satisfy the minimum irrigation quality requirement. Therefore, tannery, dyeing, pharmaceutical effluents were considered unsuitable for irrigation in agriculture.

\section{References}

[1] Buchholz, R. A. 1998. Principles of Environmental Management. London, UK. The Greening of Business, 2nd. Prentice-Hall.

[2] Soon, Y. K., Bates, T. E. and Moyer, J. R. 1978. "Land Application of Chemically Treated Sewage Sludge II. Effects on Plant and Soil Phosphorus. Potassium, Calcium and Magnesium and Soil pH.” J. Environ. Qual.7: 269-74.

[3] Soon, Y. K., Bates, T. E., and Moyer, J. R. 1980. "Land Application of Chemically Treated Sewage Sludge III. Effects on Soil and Plant Heavy Metal Contents.” J. Environ. Qual.9: 497-504.

[4] Ajmal, M., and Khan, A. U. 1984. "Effects of Vegetables Ghee Manufacturing Effluent on Soil and Crop Plants.” Env. Pollution (Series A) 34: 367-79.

[5] Ajmal, M., and Khan, A. U. 1984b. "Effects of Brewery Effluent on Agricultural Soil and Crop Plants.” Env. Pollution (Series A) 33: 341-51.

[6] Olayinka K. O. 2004. "Studies on Industrial Pollution in Nigeria: The Effect of Textile Effluents on the Quality of Groundwater in Some Parts of Lagos.” Nigerian J.Health and Biomedical Sci. 3: 44-50.

[7] Anonymous. 2005. Factsheet 11, Pollution, Available at www.sardc.net/imercsa/, SARDC.

[8] Hossain, M. T. 1998. "Effect of Industrial Effluents on 
Growth and Yield of Rice (Oryza sativa L.).” M.S. thesis. Bangabandhu Sheikh Mujibur Rahman Agricultural University, Salna, Gazipur.

[9] Kumar, H. D. 1990. Modern Concept of Ecology. New Delhi: Vikas Publishing House Pvt. Ltd., 218-75.

[10] Agrawal, S. K., Swanlalat, R., and Deubey, P. S. 1996. Biodiversity and Environment. New Delhi: APH Publishing Corporation, 179-184.

[11] Jackson, M. L. 1967. Soil Chemical Analysis. New Delhi: Prentice Hall of India Private Limited.

[12] Anonymous. 2002. Official Methods of Analysis. AOAC (Association of Official Analytical Chemists). Maryland, USA. 17th. Ed., Association of Official American Chemists.

[13] Murphy, J., and Riley, J. P. 1962. A Modified Single Solution Method for Determination of Phosphate in Natural Waters. Analytica Chemica Acta. 27: 31-36. N, P, $\mathrm{K}$ and $\mathrm{pH}$ in Continuous No-Tillage Corn Production. P.6-10. M.D. Mullen and B.N. Duck (ed.) Proc. 1992 Southern Conservation Tillage Conference. Tenn. Agric. Exp. Stn. Spec. Publ. 92-01.

[14] Page, A. L., Miller, R. H. and Keeney, D. R. 1982. "Methods of Soil Analysis. Wisconsin, USA.” Chemical and Micro-Biological Properties, Second edition.

[15] Piper, C. S. 1996. Soil and Plant Analysis. New York. Inter Science Publishers Inc.

[16] Lindsay, W. L., and Norvell, W. A. 1978. "Development of DTPA Soil Test for Zinc, Iron, Copper and Manganese.” Soil Sci. Soci. Amer. J. 42: 421-8.

[17] IRRI (International Rice Research Institute). 1998. Irristat for Windows, Version 4.3. Los Banos, Laguna, Phillippines. Biometric unit, International Rice Research Institute.

[18] Tang, Q. Y., and Feng, M. G. 2002. DPS (Data Processing System) for Practical Statistics. Beijing: Science Press.

[19] Ayers, R. S., and Wescot, D. W. 1985. "Water Quality for Agriculture.” FAO Irrigation and Drainage Paper. 29 Rev. (1): 196-8.

[20] Tiwari, R. C., Kumer, A. and Misra, A. K. 1996. "Influence of Treated Severe and Tube Well Water Irrigation with Different Fertilizer Levels on Rice and Soil Properties.” J. Indian Soc. Soil Sci., 44 (3): 547-9.

[21] Begum, R. A. 2006. "Assessment of Water and Soil Pollution and Its Effect on Rice and Red Amaranth.” Ph.D. thesis. Bangladesh Agricultural University. Mymensingh.

[22] Richards, L. A. 1968. Diagnosis and Improvement of saline and Alkali soils. Agricultural Handbok 60. New Delhi. USDA and IBH. Publishing Co. Ltd.

[23] Jahinger, M. 1999. "Effect of Industrial Waste Water on the Performance of Tomato and Soil Chemical Properties in Pot Culture.” M.S. thesis. Bangabandhu Sheikh Mujibur Rahman Agricultural University, Salna, Gazipur.

[24] WHO. 1971. World Health Organization. International Standards for Drinking Water. Cited from Ground Water Assessment Development and Management, pp. 248-9.

[25] Hussain, F., Malik, S.A., Athar, M., Bashir, N., Younis, U., Assan, M. and Mahmood, S. 2010. "Effect of tannery effluents on seed germination and growth of two sunflower cultivars.” Asian J. Biotech. 9 (32):5113-5120.

[26] Osaigbovo, A. Ulamen and Robert, O. E. 2006. "Influence of Pharmaceutical Effluent on Some Soil Chemical Properties and Early Growth of Maize (Zea mays L).” African J. Biot. 5 (12): 1612-7.

[27] Todd, D. K. 1980. Ground Water Hydrology, 2nd ed. New York: John Wiley and Sons. Inc.

[28] Bohn, R. C., Tailor, C. P., and Aron, M. P. 1985. "Impact of Industrial Effluent on Crop Growth.” J. Agric. Food Chem. 33: 865-74.

[29] Wilcox, L. V. 1995. Classification and Use of Irrigation Water. Washington: United States Dept. Agril. Cicular, No. 969, p. 19.

[30] Sarker, B. C., Zaman, M. W., Biswas, J. K., Rahmatullah, N. M., and Uddin, M. N. 2003. "Ionic Toxicity and Suitability Assessment of Waste Water and Pond Water for Irrigated Agriculture in Narayanganj District of Bangladesh.” Bangladesh J. Agril. Res. 28 (3): 291-300.

[31] Weimberg, R., Lerner, H. R., and Polijakoff-Mayber, A. 1984. "Changes in Growth and Water Soluble Solute Concentrations in Sorghum Bicolor Stressed with Sodium and Potassium Salts.” Physiol. Plant. 62: 472-80.

[32] Papp, J. C., Ball, M. C., and Terry, N. 1983. “A Comparative Study of the Effect of Nacl Salinity on Respiration, Photosynthesis and Leaf Extension Growth in Beta Vulgaris (Sugarbeet) Plant." Cell and Environ. 6: 675-7.

[33] Ahmed, J. U., and Goni, M. A. 2010. "Heavy Metal Contamination in Water, Soil, and Vegetables of the Industrial Areas in Dhaka, Bangladesh.” Environ Monit Assess.166: 347-57. 